\title{
Functions of Astrocytes and their Potential As Therapeutic Targets
}

\author{
Harold K. Kimelberg* and Maiken Nedergaard ${ }^{\dagger}$ \\ *Ordway Research Institute, 150 New Scotland Avenue, Albany, New York 12208; and ${ }^{\dagger}$ Center for Translational Neuromedicine, \\ Department of Neurosurgery, University of Rochester Medical School, 601 Elmwood Avenue, Rochester, New York 14642
}

Summary: Astrocytes are often referred to, and historically have been regarded as, support cells of the mammalian CNS. Work over the last decade suggests otherwise- that astrocytes may in fact play a more active role in higher neural processing than previously recognized. Because astrocytes can potentially serve as novel therapeutic targets, it is critical to understand how astrocytes execute their diverse supportive tasks while maintaining neuronal health. To that end, this review focuses on the supportive roles of astrocytes, a line of study relevant to essentially all acute and chronic neurological diseases, and critically re-evaluates our concepts of the functional properties of astrocytes and relates these functions and properties to the intricate morphology of these cells. Key Words: Astrocytes, potassium buffering, $\mathrm{pH}$ control, receptors, transmitter uptake, blood flow, aquaporins, lactate shuttle, antioxidant, Müller cells, ensheathment.

\section{INTRODUCTION}

The human brain consists of approximately $10^{12}$ cells, of which approximately $10^{11}$ are considered to be neurons, and the remaining $9 \times 10^{11}$ are glia. ${ }^{1}$ Astroglia, often called astrocytes, are one of the major types of glial cell. ${ }^{2}$ The brains of smaller mammalian creatures, naturally, have a smaller number of cells; and the ratio of astrocytes to neurons also declines. ${ }^{3}$ The term astrocyte derives from a combination of a Greek word for star (astron; plural, astra) and the scientific word for cell (cyte, which is in turn derived from the Greek word kytos, meaning vessel). As they were originally visualized in the late 19th and early 20th century by Golgi's reazione nera (i.e., black reaction) (FIGS. 1A-1C), astrocytes do not look much like the stars as we see them, however misleadingly, with the naked eye. These early drawings of protoplasmic astrocytes are exactly the same as we see them now with modern techniques of visualization, such as by filling the cells with dye (FIG. 1D). Some are rather like a tree's root ball or an ornamental bushy shrub. Some astroglia do not look even most fancifully look like stars but are elongate and have a number of branches that retain the elongate appearance and ori-

Address correspondence and reprint requests to: E-mail: hkimelberg@ ordwayresearch.org; or Maiken_Nedergaard@URMC.Rochester.edu. entate along the main axis of the cell (FIGS. 1B and 1C). However, the etymology of the word used to describe something is, after all, not that significant, although it can be helpful if it has some connection with the thing itself, as invoking some clear aspect of it and as an aidemémoire. The key question is whether a definition, used precisely, describes the characteristics accurately (and whether all can agree on those characteristics).

So why are all the cells that are termed astroglia considered to be astroglia, and the corollary, what cells should be termed astroglia? The term glia originated in the $1850 \mathrm{~s}^{4}$; it is now quite misleading, and therefore unhelpful. If it means anything at all, it refers to all the electrically nonexcitable (i.e., non-neuronal) cells, but the only thing they have in common is that they are not neurons and therefore are, by definition, nonexcitable. It is odd that in the experimental sciences tradition and history are so strong; otherwise we could more informatively rename neurons as excitable neural cells and glia as nonexcitable neural cells, using neural to refer to any cell of the CNS.

The objective of this review, for now, is to communicate to you, the reader, our view of what mature mammalian astrocytes are and what they most likely do. The latter, naturally, relates to the question of whether astrocytes could be useful or effective targets for drugs. It is important to point out up front that most of our concepts 


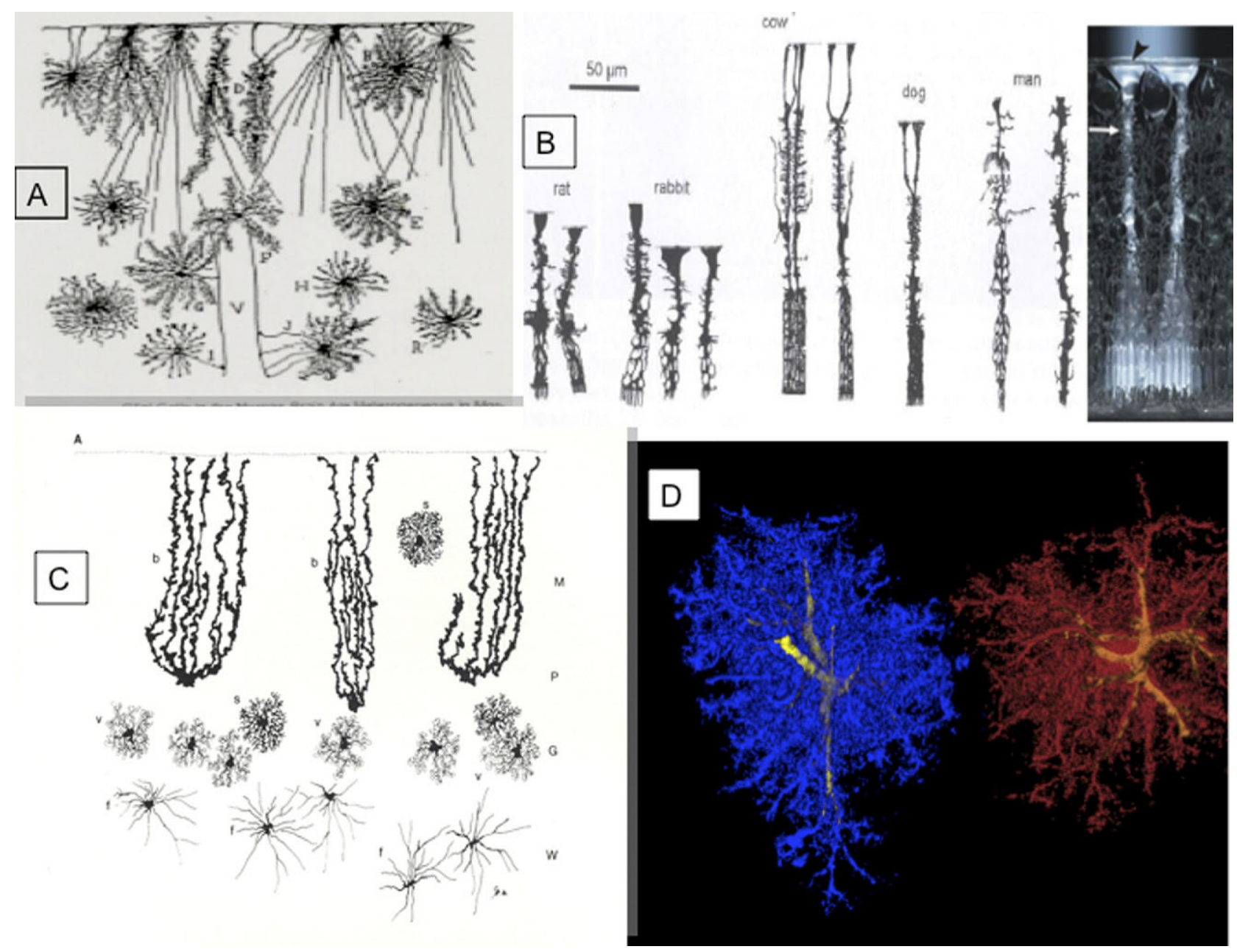

FIG. 1. (A) Golgi-stained astrocytes from a 2-month-old human infant in molecular and layers II and III of the cerebral cortex. A, B, C, and $\mathrm{D}$ indicate cells in the first cortical lamina; $\mathrm{E}, \mathrm{F}, \mathrm{G}$, and $\mathrm{H}$ indicate cells in the second and third lamina; I and $\mathrm{J}$ indicate cells with end-feet contacting blood vessels; $V$ indicates a blood vessel (1913; from Ramón y Cajal ${ }^{97}$ ). (B) Müller cells in different species as indicated. Furthest right; Müller cells as light guides (courtesy of S. Skatchkov; from Franze et al. ${ }^{104}$ ). (C) Different astrocyte cells in mature mammalian cerebellum with Golgi staining (1885; from Golgi $\left.{ }^{96}\right)$. Working down from the cerebellar surface A the top, represented by dotted line: $M=$ molecular; $P=$ Purkinje; $G=$ granule cell; $W=$ white matter layers; $b=B e r g m a n n$ glia; $s=$ protoplasmic astrocytes; $v=$ velate astrocytes; $f=$ fibrous astrocytes. (D) Dye-filled astrocytes of rat hippocampus (courtesy of Eric Bushong, personal communication).

regarding astrocytic functions are based on analysis of cultured astrocytes. Astrocytes in culture are flat cells, resembling epithelioids, that differ fundamentally from astrocytes in situ. Many of the properties of astrocytes in situ are still debated, mainly because it is difficult to study these nonexcitable cells, intermingled as they are with the multiple other cell types of the CNS, including neurons, oligodendrocytes, microglial cells, vascular cells, and more. Another problem is that we do not have a good functional endpoint by which we can assess astrocytic function. Moreover, a defining feature of astrocytes is that they are plastic cells that rapidly change in response to alterations in their environment. For example, astrocytes display reactive changes shortly after the brain slices have been prepared, and they re-express nestin, a marker of immature glial cells, a mere few hours after preparation. Astrocytes express a large number of receptors, which are primarily G-protein linked, and respond to essentially all neurotransmitters, neuromodulators, and hormones by changes in cytosolic $\mathrm{Ca}^{2+}$ or cAMP. Nonetheless, it is difficult to target astrocytes specifically, because most of the receptors are expressed also by other cell types.

Here we present a short update on current concepts with regard to the function of astrocytes and emphasize the functions that have been definitively demonstrated in the intact CNS.

\section{DEFINITION AND MORPHOLOGY OF ASTROCYTES}

Mature astrocytes come in three variants: the spherically bushy form, the less bushy process-bearing form, and the elongated, nonexcitable form. The first two are 
Table 1. Classification of Normal Mature Astrocytes

\begin{tabular}{cl}
$\begin{array}{c}\text { Star-shaped } \\
\text { astroglia }\end{array}$ & \\
1. & Protoplasmic astrocytes in the gray matter \\
2. & Fibrous astrocytes in the white matter \\
Elongate & \\
astroglia & \\
3. & $\begin{array}{l}\text { Müller cells spanning the retina } \\
\text { Bergmann glia in the molecular layer of } \\
\text { the cerebellum }\end{array}$ \\
\hline
\end{tabular}

the protoplasmic astrocytes of gray matter (FIGS. 1A and 1D) and the fibrous astrocytes of white matter (FIG. 1C), respectively. The elongated cells are the Bergmann glia of the cerebellum (W in FIG. 1C) and the Müller cells of the retina (FIG. 1B; Table 1). This description of mature astrocytes dates back to the first great period of neurohistology, and is essentially unchanged since the latter decades of the nineteenth and the early part of the twentieth century. ${ }^{5,6}$

The illustrations in FIG. 1 are all of rat brain, except FIG. 1A, which is an older drawing of a slice prepared from a human infant brain. FIG. 2 shows protoplasmic astrocytes from the cerebral cortex of an adult mouse, a rhesus monkey, and a human. The bushy morphology of the dye-labeled cells is the same, but it was found that the mouse astrocyte domain (soma plus processes) was about 2.5 times smaller than the human. ${ }^{7}$ This was based on dye labeling, as well as glial fibrillary acidic protein (GFAP) staining, which in the rodent shows only the soma and the largest parts of the process most proximate to the soma (FIG. 1D). Also characteristic of primate astrocytes are long, varicosity-bearing processes that extend beyond the domains of the bushy processes and extend between the cortical lamina, which have been suggested to optimize the columnar organization of the cerebral cortex of primates. $^{8}$ Whether this is to effect some higher level of coordination within the cortical columns has not yet been determined (and will be difficult to determine). The apparent larger size of the domains of the protoplasmic astrocytes of larger-brained primates could serve, at its simplest, to limit the expansion of the astrocyte population (i.e., to control more synapses with fewer astrocyte somas).

Presumed astrocyte-specific proteins are used as markers to identify astrocytes, especially to identify cells recorded in situ after the cell has been filled with a dye present in the microelectrode. This is now increasingly being supplemented by use of presumed astrocyte-specific promoters to drive synthesis of fluorescent proteins. This latter technique has the advantage that the cells to be studied can be preselected in living tissue. These techniques have recently been reviewed for neurons ${ }^{9}$ and for astrocytes. ${ }^{10}$ However, proteins are responsible for most cellular activities and are therefore also subject to change. Similarly, promoter activation can also change. Protein markers that are generally used for astrocytes are glial fibrillary acidic protein (GFAP), which is an intermediate filament protein, and the glutamate transporters named GLAST and GLT-1 for rat brain and EAAT-1 and EAAT-2 (the EAA stands for excitatory amino acids) for human brain. Other EAAT isoforms are found on neurons. GFAP was the first astrocyte marker widely used and has stood the test of time well, such that all cells that

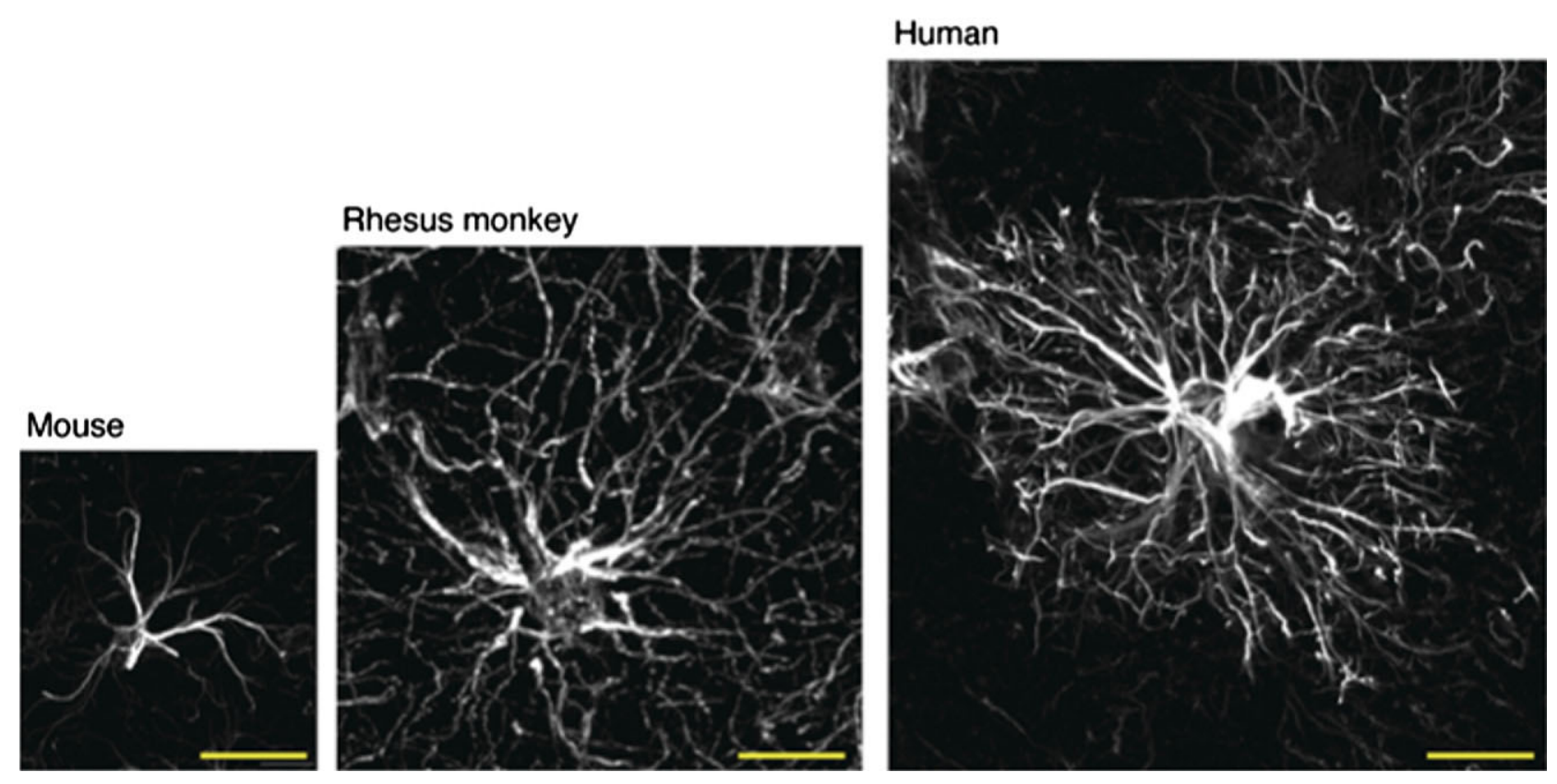

FIG. 2. The size of astrocytes increases with increasing complexity of brain function. Comparison of glial fibrillary acidic protein (GFAP)-labeled astrocytes in cortex of mouse, rhesus monkey, and human brain. Scale bar: $50 \mu \mathrm{m}$. 
robustly express GFAP are astrocytes. The converse, however, does not appear to hold, and it is recognized that there a number of other proteins and physiological properties that define astrocytes, so that one can have a GFAP-negative cell that should nonetheless be called an astrocyte because it has these other properties. Of course, it also must be established that it is not another nonexcitable neural cell, like the NG2-positive cells that were at one time considered to be smooth protoplasmic astrocytes, based on their morphology and location in gray and white matter. ${ }^{11}$

The water channel protein aquaporin 4 , another good marker for astrocytes, is predominantly localized in the perivascular membranes of protoplasmic astrocytes. This protein facilitates water transport, but under what conditions it is needed is less clear. ${ }^{12}$ Recent microarray studies for isolated astrocytes ${ }^{13,14}$ have turned up still other good candidates, especially aldehyde dehydrogenase 1 family, member L1 (ALDH1L1; also known as 10formyltetrahydrofolate dehydrogenase), which was quite unexpected.

The passive electrical properties of mature astrocytes, which are due to their highly selective leak $\mathrm{K}^{+}$channels, are a well-established characteristic of astrocytes that, after a confusing period when it was questioned based on results from primary cultures and recordings from immature astrocytes, ${ }^{15}$ has been reestablished and is now used as a diagnostic of mature protoplasmic astrocytes in situ (see, for example, Houades et al. ${ }^{16}$ and Henneberger et al. ${ }^{17}$ ). It has not been so clearly established for the other astrocytes. It confers on the cells a linear I-V curve with a reversal potential close to the $\mathrm{K}^{+}$equilibrium potential and a very low membrane resistance of a few megohms that makes single-electrode whole-cell voltage clamping impossible, not in the sense of doing it, but in the interpretation of the results. ${ }^{6,18,19}$ It also results in current not spreading further than closest (nearest neighbor) astrocytes. ${ }^{20}$

Other characteristics that are used to identify astrocytes are one or more processes touching a blood vessel (FIG. 1A) and communication among up to 100 astrocytes by means of gap junctions located at the tips of joined processes (see, for example, Giaume et al. ${ }^{21}$ ).

\section{FUNCTIONS OF MATURE PROTOPLASMIC ASTROCYTES}

\section{Support functions}

A long-held principle in biology is that form and function are closely interrelated. It is often expressed as function follows form. Thus, the large number of fine processes of especially the protoplasmic astrocytes and their endings on blood vessels and synapses (FIGS. 1A and 1D) is an important jumping-off place when considering astrocyte function. In Table 2, we summarize the basic support functions of astrocytes, defined as functions that allow neurons and the brain in general to function optimally (for more discussion of this issue, see Kimelberg $\left.^{5,6}\right)$. Some original references are listed, to indicate the approximate time when the idea was first proposed. This is a difficult task, especially to correctly identify who really had priority, and then not to give offence by omission. Many of the original suggestions are from studies with cultures, which are correct in some generalities but unpredictably in error for specifics. ${ }^{6}$ Subsequent reviews are also listed, and these may be consulted to sort out the details.

We now cover the topics summarized in Table 2, item by item.

Item 1: $\left[\mathrm{K}^{+}\right]_{\mathbf{o}}$ buffering. The first dynamic studies on glial cells were electrophysiological (at the time, in the mid 1960s, this was the only cell-specific physiological technique that could be used in situ) and were done in the amphibian optic nerve. Amphibian tissue was easier to work with than mammalian tissue. Only cell bodies could be impaled, and this was actually an advantage, because all the cell bodies in the optic nerve are glia.

Two important findings emerged from these studies. One was that these glia were found to be nonexcitable and the other was that they had very negative membrane potentials, determined essentially exclusively by the transmembrane $\mathrm{K}^{+}$gradient. ${ }^{22}$ These amphibian optic glia were likely best described as astrocytes, but important later work in cats showed that the same characteristics apply to recorded astrocytes, identified histologically after recording, in the adult mammalian cortex. ${ }^{23}$ Concurrently, studies of cultured cells indicated that astrocytes have a much higher capacity for $\left[\mathrm{K}^{+}\right]_{\mathrm{o}}$ uptake than neurons. Increasing $\left[\mathrm{K}^{+}\right]_{\mathrm{o}}$ led to a $50 \%$ increase in $\mathrm{K}^{+}$content in astrocytes within seconds and to a doubling within 1-2 minutes. ${ }^{24}$

It was proposed that the exclusive $\mathrm{K}^{+}$permeability confers on glia a function of maintaining a constant extracellular $\mathrm{K}^{+}$concentration in the face of neuronal activity that would tend to increase it. ${ }^{25}$ The process, termed $\mathrm{K}^{+}$spatial buffering, involves redistribution of increased $\left[\mathrm{K}^{+}\right]_{\mathrm{o}}$ by a current loop set up by a membrane potential difference that is due to locally increased $\left[\mathrm{K}^{+}\right]_{\mathrm{o}}$ and that serves to dissipate the increased $\left[\mathrm{K}^{+}\right]_{\mathrm{o}}$ to distant sites (hence the term spatial buffering). ${ }^{26,27}$ It was an ingenious speculation, assigning a function for the exclusive $\mathrm{K}^{+}$conductance of the astroglial membrane and seemingly further supported by the organization of the cells into syncytia, which could, in theory, carry the currents for long distances. The evidence, however, was actually very indirect. A major critique of the model is that the current cannot spread, given the low resistance of the astrocyte, ${ }^{18}$ in relation to the gradients of increased $\left[\mathrm{K}^{+}\right]_{\mathrm{o}}$ that can be generated by neuronal activity. In fact, recent studies could not confirm that spatial buffering of 
Table 2. Classification of Normal Mature Astrocytes

\begin{tabular}{|c|c|c|}
\hline Support Function & Original References & Reviews \\
\hline $\begin{array}{l}\text { 1. } \mathrm{K}^{+} \text {buffering } \\
\text { Originally, spatial redistribution of } \mathrm{K}^{+} \text {was proposed to } \\
\text { be carried by a current loop, based on the near- } \\
\text { exclusive conductance of the astrocytic membrane to } \\
\mathrm{K}^{+} \text {, but that hypothesis has not been confirmed. Other } \\
\text { transporter uptake systems have not been shown to } \\
\text { exhibit the right kinetics or affinity characteristics, and } \\
\text { have also not been shown to be directly involved in } \\
\mathrm{K}^{+} \text {uptake. For example, the } 3 \mathrm{Na} / 2 \mathrm{~K} \text { ATPase is most } \\
\text { sensitive to [Na]i and is } 90 \% \text { saturated at the normal } \\
{[\mathrm{K}] \text { o of } 3 \mathrm{mM} \text {. See text. }}\end{array}$ & $\begin{array}{l}\text { Orkand et al. }(1966)^{25} \\
\text { Lothman and Somjen } \\
\quad(1975)^{115} \\
\text { Dietzel et al. }(1980)^{116} \\
\text { Kimelberg }(1987)^{117} \\
\text { McGrail and Sweadner } \\
\quad(1986)^{118}\end{array}$ & $\begin{array}{l}\text { Leis et al. }(2005)^{119} \\
\text { Somjen }(2004)^{120}\end{array}$ \\
\hline $\begin{array}{l}\text { 2. Control of }\left[\mathrm{H}^{+}\right]_{\mathrm{o}} \\
\text { Control of extracellular } \mathrm{pH} \text { is due to a number of } \mathrm{H}^{+} \\
\text {and } \mathrm{HCO} 3^{-} \text {transporting enzymes in astrocytes, } \\
\text { together with carbonic anhydrase activity. }\end{array}$ & $\begin{array}{l}\text { Tschirgi }(1958)^{40} \\
\text { Kimelberg et al. }(1979)^{42}\end{array}$ & $\begin{array}{l}\text { Deitmer and Rose }(2010)^{121} \\
\text { Obara et al. }(2008)^{122} \\
\text { Chesler }(2003)^{123}\end{array}$ \\
\hline $\begin{array}{l}\text { 3. Functions of astrocyte receptors } \\
\text { Astrocytes in situ express mainly metabotropic } \\
\text { receptors that act to mobilize intracellular } \mathrm{Ca}^{2+} \text { stores, } \\
\text { or other secondary messenger systems, such as cAMP. } \\
\text { Very few studies have addressed the roles of } \mathrm{Ca}^{2+} \\
\text { signaling or cAMP in the supportive roles of } \\
\text { astrocytes. }\end{array}$ & $\begin{array}{l}\text { van Calker et al. } \\
(1979)^{124} \\
\text { McCarthy and De Vellis } \\
(1978)^{125}\end{array}$ & $\begin{array}{l}\text { Halassa et al. }(2007)^{126} \\
\text { Volterra and Meldolesi } \\
\quad(2005)^{127} \\
\text { Newman }(2004)^{128} \\
\text { Kimelberg }(1988)^{54}\end{array}$ \\
\hline $\begin{array}{l}\text { 4. Uptake of glutamate and GABA } \\
\text { Two very important roles of astrocytes are clearance of } \\
\text { glutamate and GABA. }\end{array}$ & $\begin{array}{l}\text { Berl et al. }(1961)^{58} \\
\text { Martinez-Hernandez et al. } \\
\quad(1977)^{129} \\
\text { Schousboe et al. }(1977)^{130} \\
\text { Levi et al. }(1983)^{131}\end{array}$ & $\begin{array}{l}\text { Sattler and Rothstein } \\
(2006)^{132} \\
\text { Anderson and Swanson } \\
\quad(2000)^{133}\end{array}$ \\
\hline $\begin{array}{l}\text { 5. Control of cerebral blood flow } \\
\text { Perivascular end-feet completely surround all parts of } \\
\text { the vasculature in the CNS. Astrocytes with their } \\
\text { perisynaptic and vascular processes are in an ideal } \\
\text { position to regulate vascular tone. Prostaglandin E2 } \\
\text { (PGE2) is a key vasodilator released by astrocytes. }\end{array}$ & Zonta et al. $(2003)^{70}$ & $\begin{array}{l}\text { Koehler et al. }(2009)^{78} \\
\text { Iadecola and Nedergaard } \\
\qquad(2007)^{81}\end{array}$ \\
\hline $\begin{array}{l}\text { 6. Water transport and aquaporin } 4 \\
\text { AQP4 is specifically expressed by astrocytes and is } \\
\text { primarily located in the perivascular process. AQP4 } \\
\text { facilitates water transport, but may also be involved in } \\
\text { exchange of gases, including } \mathrm{O}_{2}, \mathrm{CO}_{2} \text {, and NO. }\end{array}$ & Nielsen et al. $(1997)^{134}$ & $\begin{array}{l}\text { King et al. }(2004)^{135} \\
\text { Amiry-Moghaddam and } \\
\text { Ottersen }(2003)^{84}\end{array}$ \\
\hline $\begin{array}{l}\text { 7. Astrocyte-neuronal lactate shuttle (hypothesis) } \\
\text { This hypothesis proposes that glucose, constantly } \\
\text { transported into the brain from the blood, is converted } \\
\text { to lactate in the astrocyte and is then exported to } \\
\text { neurons as their major fuel source. There is no doubt } \\
\text { about existence of this metabolic pathway, but neuronal } \\
\text { metabolism also depends on glucose. }\end{array}$ & $\begin{array}{l}\text { Pellerin and Magistretti } \\
\qquad(1996)^{136}\end{array}$ & $\begin{array}{l}\text { Magistretti }(2009)^{137} \\
\text { Dienel and Cruz }(2004)^{138}\end{array}$ \\
\hline $\begin{array}{l}\text { 8. Antioxidant functions } \\
\text { Astrocytes contain a relative higher amount of several } \\
\text { key proteins involved in neutralizing damaging free } \\
\text { radicals in the form of reactive oxygen species. }\end{array}$ & Aschner $(2000)^{102}$ & Jou $(2008)^{139}$ \\
\hline $\begin{array}{l}\text { 9. Müller cells as living light guides } \\
\text { According to a recent proposal, the columnar Müller } \\
\text { cells serve to direct light to the back of the retina } \\
\text { where the photoreceptors are located. }\end{array}$ & Franze et al. $(2007)^{104}$ & \\
\hline $\begin{array}{l}\text { 10. Peri-synaptic processes } \\
\text { Processes of astrocytes wall off groups of neurons and } \\
\text { their synapses. Retraction of such ensheathment } \\
\text { results in increased interaction between neurons and } \\
\text { increased release of hormones secreted from the } \\
\text { neurons, such as the oxytocin/vasopressin secreting } \\
\text { neurons in the supraoptic nucleus. }\end{array}$ & $\begin{array}{l}\text { Hatton et al. }(1992)^{140} \\
\text { Deleuze et al. }(1998)^{141}\end{array}$ & Theodosis et al. $(2008)^{142}$ \\
\hline
\end{tabular}




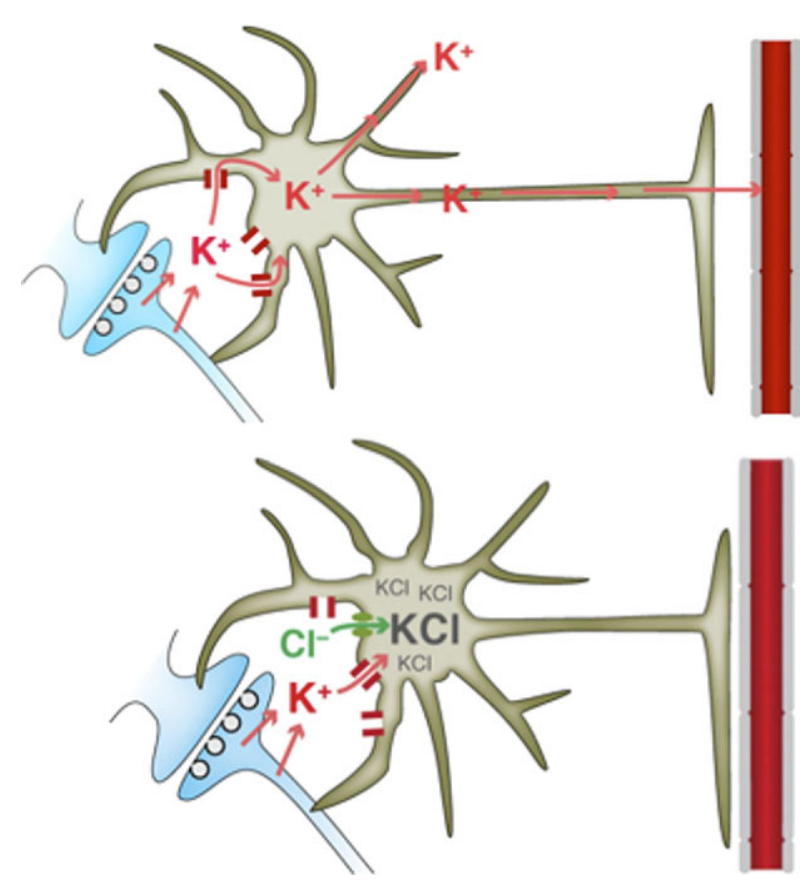

FIG. 3. Schematic diagram of the two major mechanisms proposed to be involved in astrocytic buffering of excess $\left[\mathrm{K}^{+}\right]_{\mathrm{o}}$. In potassium siphoning, $\mathrm{K}^{+}$diffuses via gap junctions and is released distant to the site of uptake and may increase local blood flow. In the second proposed mechanism of astrocytic $\mathrm{K}^{+}$buffering, $\mathrm{K}^{+}$and $\mathrm{Cl}^{-}$are taken up in equivalent amounts and accumulate locally in astrocytes.

$\left[\mathrm{K}^{+}\right]_{\mathrm{o}}$ plays a role in neurovascular coupling in retina, ${ }^{28}$ or that gap junctions contribute to $\mathrm{K}^{+}$buffering in hippocampus. ${ }^{29}$

Two major mechanisms involved in astrocytic $\left[\mathrm{K}^{+}\right]_{\mathrm{o}}$ buffering are presented schematically in FIG. 3 .

The clearance of increasing $\left[\mathrm{K}^{+}\right]_{\mathrm{o}}$ due to neuronal activity may however not be limited to passive influx of $\mathrm{K}^{+}$driven by its electrochemical gradient, but could include other $\mathrm{K}^{+}$uptake mechanisms. These included $\mathrm{K}^{+}$uptake by the $\mathrm{Na}^{+} / \mathrm{K}^{+}$pump, and cotransporters belonging to the $S L C 12 A$ gene family. D'Ambrosio et al. ${ }^{30}$ concluded that inwardly rectifying $\mathrm{K}^{+}$channels $\left(\mathrm{K}_{\mathrm{ir}}\right.$ channels) are primarily responsible for regulation of baseline $\left[\mathrm{K}^{+}\right]_{\mathrm{o}}$, whereas the $\mathrm{Na}^{+} / \mathrm{K}^{+}$pump determines the rate of $\left[\mathrm{K}^{+}\right]_{\mathrm{o}}$ recovery after excessive neuronal firing in hippocampal slices. A similar conclusion was reached by Walz and Wuttke in two articles. ${ }^{31,32}$ Their analysis of reactive astrocytes in hippocampus suggested that astrocytes limit increases in $\left[\mathrm{K}^{+}\right]_{\mathrm{o}}$ by a combination of uptake via the $\mathrm{Na}^{+} / \mathrm{K}^{+}$pump and passive influx. A potential critique of the proposed role of the $\mathrm{Na}^{+} / \mathrm{K}^{+}$pump is that the pump responds most effectively to changes in $\left[\mathrm{Na}^{+}\right]_{\mathrm{i}}$, to pump out, whereas its outside $\mathrm{K}^{+}$binding site is $\sim 90 \%$ saturated at the normal $\left[\mathrm{K}^{+}\right]_{\mathrm{o}}$ of $3 \mathrm{mmol} / \mathrm{L} .^{31}$ Thus, clearance of $\left[\mathrm{K}^{+}\right]_{\mathrm{o}}$ by the $\mathrm{Na}^{+} / \mathrm{K}^{+}$pump must be accompanied by increases in intracellular $\mathrm{Na}^{+}$(which is a possibility, in that several transporters and receptors, including GLT1, GT1, NMDA, and P2X receptors, facilitate $\mathrm{Na}^{+}$influx and are activated during synaptic activity $^{33-36}$ ).

Another proposed mechanism is channel-mediated uptake of increased $\left[\mathrm{K}^{+}\right]_{\mathrm{o}}$ and $\mathrm{Cl}^{-}$driven by the Donnan potential. ${ }^{37}$ However, this mechanism requires $\mathrm{Cl}^{-}$channels in addition to $\mathrm{K}^{+}$channels, ${ }^{38}$ and there is little evidence for open $\mathrm{Cl}^{-}$channels under the mildly elevated $\left[\mathrm{K}^{+}\right]_{\mathrm{o}}$ levels seen, for example, during normal neuronal activity. ${ }^{39}$ Nonetheless, reactive astrocytes have a significant resting $\mathrm{Cl}^{-}$conductance, and passive uptake of $\mathrm{K}^{+}$may contribute to $\mathrm{K}^{+}$buffering in gliotic scars. ${ }^{31}$

In conclusion, strong evidence obtained in in vitro systems support the concept that astrocytes are engineered to buffer the increases in extracellular $\mathrm{K}^{+}$that may occur in connection with neural activity, whereas the $\left[\mathrm{K}^{+}\right]_{\mathrm{o}}$ reuptake mechanisms in neurons seem to be less efficient and slower. Intact brain also has a very high capacity for rapid normalizing of excess $\left[\mathrm{K}^{+}\right]_{\mathrm{o}}$, but it has been difficult to separate the roles of astrocytes versus neurons in $\left[\mathrm{K}^{+}\right]_{\mathrm{o}}$ buffering. The pharmacological approaches available for study of $\left[\mathrm{K}^{+}\right]_{\mathrm{o}}$ buffering do not enable specific targeting to a single cell type. Nevertheless, the very large number of membrane transporters expressed by astrocytes that facilitate fluxes of ions across the plasma membrane suggest that astrocytes are heavily involved in regulation of extracellular ion homeostasis. However, $\left[\mathrm{K}^{+}\right]_{\mathrm{o}}$ buffering is at this point not an attractive target for prevention of, for example, epilepsy or postischemic spreading depression waves, because of our poor understanding of the molecular mechanisms involved in $\left[\mathrm{K}^{+}\right]_{\mathrm{o}}$ uptake.

Item 2: Control of $\left[\mathbf{H}^{+}\right]_{\mathbf{o}^{*}}$. An involvement of astrocytes in brain $\mathrm{pH}$ control mechanisms was first proposed based on a localization of carbonic anhydrase in astrocytes at the blood-brain barrier, involving transport of $\mathrm{HCO}_{3}{ }^{-}$linked to acceleration of intra-astrocytic $\mathrm{CO}_{2}$ hydration. ${ }^{40}$ Subsequent studies revealed $\mathrm{Na}^{+} / \mathrm{H}^{+}$and $\mathrm{Cl}^{-} / \mathrm{HCO}_{3}{ }^{-}$exchangers and carbonic anhydrase activity in primary astrocyte cultures, ${ }^{41-43}$ and a model of coupled $\mathrm{Na}^{+} / \mathrm{H}^{+}$and $\mathrm{Cl}^{-} / \mathrm{HCO}_{3}{ }^{-}$exchange was proposed to explain astrocytic swelling under pathological conditions. These studies were what now would be consider dated culture studies, and this model is very difficult to test in situ. Other findings in primary astrocyte cultures are an electrogenic sodium proton cotransporter (3 $\mathrm{HCO}_{3}{ }^{-}$plus $2 \mathrm{Na}^{+}$), which can acidify the extracellular space when stimulated by an increased $\mathrm{K}^{+}$-dependent depolarization and alkalinize the cell interior, ${ }^{44}$ and sodium-dependent $\mathrm{Cl}^{-} / \mathrm{HCO}_{3}{ }^{-}$exchange, as well as the sodium independent $\mathrm{Cl}^{-} / \mathrm{HCO}_{3}{ }^{-}$exchanger already mentioned. ${ }^{45-47}$ All these are members of the bicarbonate transporter (BT) superfamily. Inspection of the transcriptome from isolated astrocytes ${ }^{13,14}$ shows that many of these transporters (gene symbols starting with $S L C$, 
for solute carrier), as well as other acid homeostasisrelated transporting systems, are preferentially expressed in astrocytes.

Another $\mathrm{H}^{+}$transporting system is the lactate plus $\mathrm{H}^{+}$ transporter, different isozymes of which are present in astrocytes and neurons. These systems are responsible for the efflux of lactate from astrocyte and uptake of lactate into neurons as proposed in the astrocyte-neuron lactate shuttle hypothesis ${ }^{48}$ (see further under item 7 , below). Thus, lactate transport affects $\mathrm{pH}$ levels or, viewed as the converse, $\mathrm{pH}$ can affect lactate exchange and therefore link the astrocyte-neuron lactate shuttle to changes in $\mathrm{pH}_{\mathrm{e}}$ and $\mathrm{pH}_{\mathrm{i}}$. Note that lactate transport is directly linked to $\mathrm{pH}$ because of the $\mathrm{H}^{+}$being cotransported with lactate. The end product of glycolysis is the lactate anion, and not lactic acid, so it does not directly change $\mathrm{pH}$, as is often incorrectly implied in the term lactic acidosis. ${ }^{49}$

Item 3: Function of astrocytic receptors. For some time, astrocyte depolarization was not thought to occur by activation of ionotropic receptors, based on an early study showing that depolarization of astrocytes due to application of GABA was better explained by electrogenic uptake of GABA, because no conductance changes could be measured, as expected if ionotropic astrocytic receptors were being activated. This is an argument by omission, however, and was not backed by direct findings. ${ }^{50}$ It was similarly concluded from work on neuroglia in slices that depolarization due to added glutamate was caused by elevated $[\mathrm{K}]_{\mathrm{o}}$ due to neuronal activation. ${ }^{51}$ Thus, because of these and other studies, the view arose that astroglia lack receptors and respond to changes in neuronal activity only through depolarization of their membrane potentials in response to elevated $[\mathrm{K}]_{\mathrm{o}}$.

This view simplified neuronal research, because receptor-mediated effects of neurotransmitters in intact tissue could then be attributed only to neurons, so perhaps it was accepted more readily than it should have been. The problem, however, is that this view is wrong. It would be a very unusual cell that lacked receptors, for all cells have receptors to respond to their environments, albeit many of these are metabotropic rather than ionotropic. The more reasonable view is that astrocytes express only a limited number of ionotropic receptors, which would make more biological sense, in that astrocytes, being nonexcitable, do not need to change their membrane potentials for the same purposes as neurons do. Later studies in primary astrocyte cultures showed that astrocytes have glutamate and GABA ionotropic receptors, ${ }^{52,53}$ as well as a variety of metabotropic receptors. ${ }^{54}$

Because of alterations in their gene expression, cells may express more receptors in culture than in situ, and evidence for ionotropic receptors in astrocytes in situ is more limited. ${ }^{55}$ One of these exceptions is the AMPAtype receptors of the $\mathrm{Ca}^{2+}$ permeable variety found on
Bergmann glia in situ. ${ }^{56}$ There are concentrations of vesicles in the boutons of parallel fibers abutting Bergmann glia. These give fast inward currents in the Bergmann glia because of release of glutamate from these vesicles, a process termed ectopic release. Other than a role in maintaining excitatory synapses on the Purkinje neurons for the $\mathrm{Ca}^{2+}$ influx associated with this activation, ${ }^{57}$ their functions have not yet been described. One possible function could be an increase in intracellular $\mathrm{Na}$, which would increase the activity of the $\mathrm{Na} / \mathrm{K}$ ATPase and in turn lower $[\mathrm{K}]_{\mathrm{o}}$, because the low concentration of $\mathrm{Na}^{+}$in many cells is the rate limiting step for the $\mathrm{Na} / \mathrm{K}$ ATPase.

The close similarity in neurotransmitter receptors between Bergmann glia and Purkinje neurons is depicted in FIG. 4.

Specifically targeting astrocytic receptors is, with perhaps a few exceptions, not possible, because neurons and astrocytes express receptors for the same ligand. In fact, one characteristic of astrocytes is that their receptor expression mimics surrounding neurons. Often, neurons will express both ionotropic and metabotropic receptors, whereas astrocytes express primarily metabotropic receptors.

Item 4: Uptake of glutamate and GABA. Uptake of the excitatory amino acid transmitter glutamate is arguably the best established and the most important property of mature protoplasmic astrocytes. Inactivation of glutamate then occurs by conversion to glutamine by the astrocyte-specific intracellular enzyme glutamine synthetase, consuming ATP and ammonia. Glutamine leaves the astrocyte in the perisynaptic processes (the same region in which it is normally taken up) by means of an amino acid carrier; it is then taken up by neighboring neurons, where it is reconverted to glutamate via glutaminase. ${ }^{58}$

The uptake of glutamate into a small second compartment was first proposed based on biochemical evidence that the specific activity of the glutamine product is greater than the whole brain specific activity of the injected radiolabeled glutamate, its immediate precursor. ${ }^{58}$ Obviously, if the injected radiolabeled glutamate had equilibrated with all the unlabeled glutamate present in the brain, then the specific activity of its product should have decreased. By now, a wealth of evidence has shown that specific excitatory amino acids carriers are specifically expressed in astrocytes (as is also shown by high and specific levels of mRNA) and that their knockdown leads to increased glutamate levels in the extracellular space. $^{59}$

Mature astrocytes in situ are also known to contain GABA transporters, in particular GAT-1 and especially GAT-3. ${ }^{60-62}$ These are not specific to astrocytes, however, and they are also found in neurons. The metabolic consequences of GABA uptake can be quite varied. ${ }^{63}$ There are also transporters for glycine, especially in the 


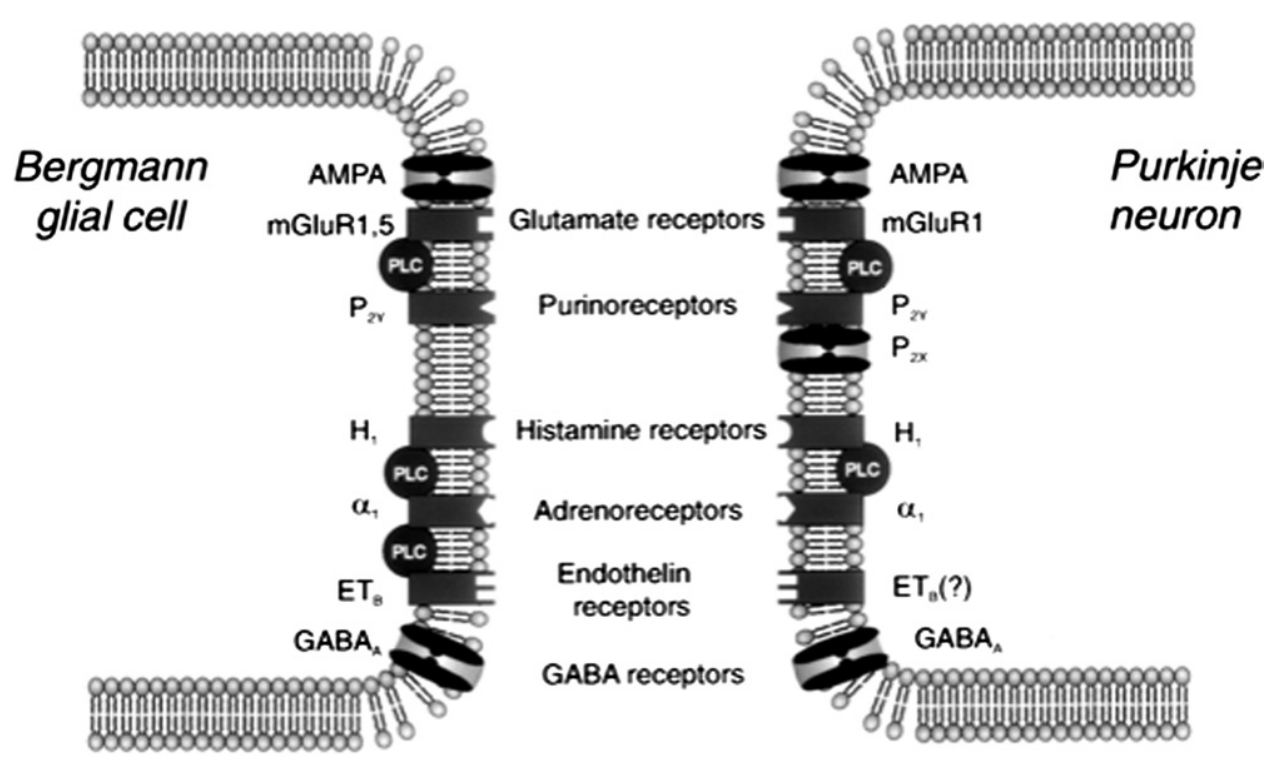

FIG. 4. Bergmann glial cells and Purkinje neurons express similar sets of neurotransmitter receptors. mGluR, metabotropic glutamate receptor. Modified from Verkhratsky et al., ${ }^{143}$ with permission.

glycine-rich posterior regions of the CNS. Of the two glycine transporters GLYT-1 and GLYT-2, the GLYT-1 transporter predominates in astrocytes; it also seems to have the more crucial role in lowering glycine levels in the CNS. (For a fuller account of the neurotransmitter transporters, see Yang and Rothstein. ${ }^{64}$ ) Taurine is also taken up by cultured astrocytes, but the role for this transmitter, also thought to have a cell osmolyte function in the brain because it is markedly released upon astrocytic swelling, is not well elucidated (see Warskulat et al. ${ }^{65}$ ).

The consequences of targeting astrocytic uptake of glutamate have already been studied, using several approaches. For example, mice lacking the astrocyte-specific glutamate transporter GLT-1 die within weeks after birth as a consequence of repeated seizures, suggesting that pharmacological manipulation of the transmitter represents a potent therapeutic target. ${ }^{59}$ In fact, Rothstein et al. ${ }^{66}$ screened 1040 FDA-approved drugs and nutritionals and found that many $\beta$-lactam antibiotics are potent stimulators of GLT-1 expression. When used in an animal model of amyotrophic lateral sclerosis, the drug delayed loss of neurons and increased mouse survival. These experiments provide an example of how a known function of astrocytes can be manipulated and of how novel classes of potential neurotherapeutics could be useful for treatment of a fatal disease. ${ }^{66}$ The $\beta$-lactam antibiotics have also been shown to reduce the severity of experimental stroke, although the mechanisms of action are debated. ${ }^{67,68}$

Item 5: Control of cerebral blood flow. Astrocyte foot processes surround all blood vessels in the brain, including the precapillary arterioles that are the basic regulators of blood flow, ${ }^{69}$ and flow effects have been shown to occur. ${ }^{70,71}$ It is necessary for the control to be exerted at the level of the arterioles, because capillaries lack the smooth muscle needed to cause contraction or relaxation to change the blood vessel diameter. ${ }^{72,73}$ The astrocytic ensheathment of CNS blood vessels originates as blood vessels penetrate the brain parenchyma early in development from the arachnoid to the brain parenchyma and carry with them the glia limitans, which consists of the end-feet of astrocytic processes. ${ }^{74}$

Interactions between the astrocytic sheath and the vascular endothelial cells are thought to be responsible for the formation of the interendothelial tight junctions that form the blood-brain barrier, which occurs at approximately the end of the first trimester in humans. ${ }^{75}$ If the role of the astrocyte is purely developmental, however, why does the vascular ensheathment persist through adulthood? Presumably, the sheaths then acquire physiological roles, or a constant astrocytic influence is needed to maintain the blood-brain barrier. Clearly, a physiological role could be met by the lactate shuttle hypothesis (item 7, below), control of ingress of compounds such as glucose and amino acids or egress of waste metabolites, ${ }^{48}$ or control of $\left[\mathrm{K}^{+}\right]_{\mathrm{o}}$ and blood flow. ${ }^{76}$

A reasonable view would be that one reason why astrocyte processes continue to surround blood vessels in the mature animal is that they are transducers of changes in neuronal activity affecting blood vessel (arteriole) diameter and therefore flow. It has been recently suggested that one of the major roles of the mGluR-related increases in intracellular $\left[\mathrm{Ca}^{2+}\right]$ in astrocytes is to activate phospholipase 2 to generate arachidonic acid and then prostaglandin 2 via cyclooxygenase-1 (COX-1) to dilate vascular smooth muscle. ${ }^{77,78}$ The astrocytes can also synthesize vasoactive epoxyeicosatrienoic acids (EETs) ${ }^{79}$ It is possi- 


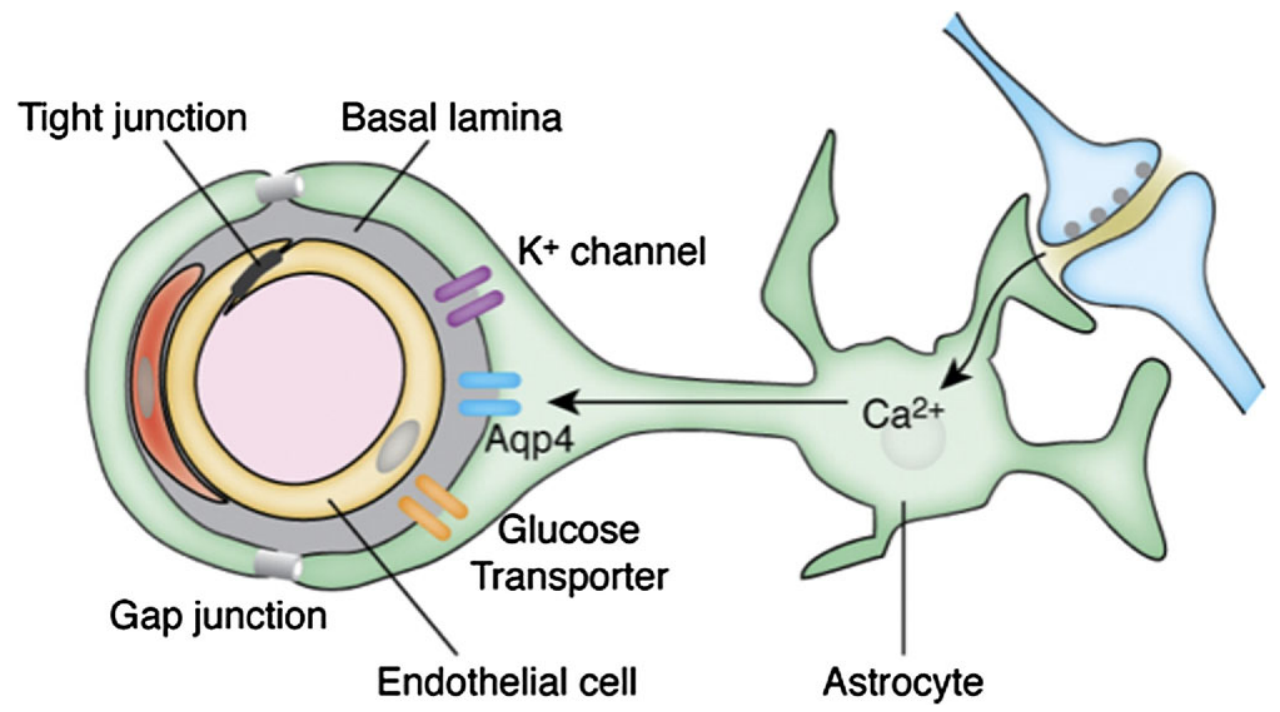

FIG. 5. Control of blood flow. Schematic diagram of the current model of the role of astrocytes in functional hyperemia. Astrocytic Ca ${ }^{2+}$ signaling is activated by synaptic spillover of glutamate, which binds to metabotropic glutamate receptors during perisynaptic glia processes. The $\mathrm{Ca}^{2+}$ increase in astrocytes triggers activation of phospholipase 2 (PLA2), resulting in release of arachidonic acid. In turn, cyclooxygenase-1 (COX-1) metabolizes arachidonic acid to prostaglandin E2 (PGE2), which mediates vasodilation.

ble that astrocytes act as transducers, which integrate local neuronal activity into either vasodilatation or constriction. Nevertheless, there is little doubt that direct innervations also play a role in regulation of vascular tone. ${ }^{80}$ (See Koehler et al. ${ }^{78}$ and Iadecola and Nedergaard ${ }^{81}$ for a recent summary of the possible neuronal, smooth muscle, and endothelial cell influences on vascular smooth muscle tone, as well as astrocyte influences.)

A current model of astrocytic control of blood flow is depicted in FIGS. 5 and 6.

The details of astrocyte regulation of blood vessel diameter and flow are now being worked out in both brain slices ${ }^{77}$ and in vivo by two-photon imaging. ${ }^{80}$ Differences have been observed between the two experimental systems, which may depend on the oxygen levels of the tissue versus the slices. ${ }^{77}$ In this regard the intact animal would, by definition, provide the normal oxygen-

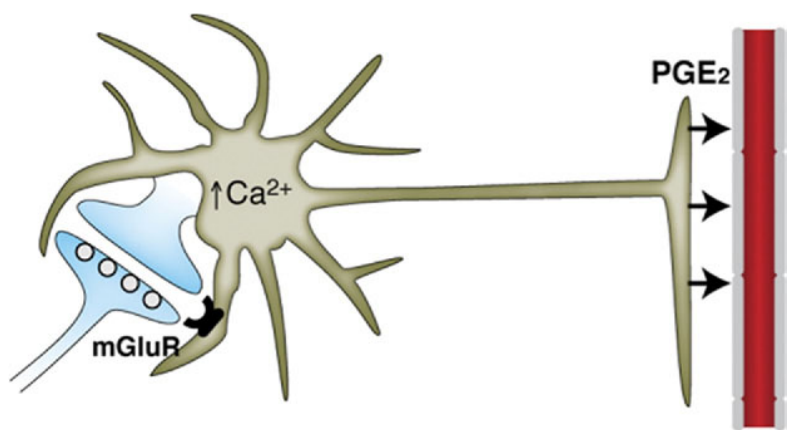

FIG. 6. A diagram of the blood-brain barrier and the position of astrocytes and their processes. The perisynaptic and perivascular processes of astrocytes link synapses and the vasculature. More than $90 \%$ of AQP4 is present in perivascular end-feet of astrocytes, whereas endothelial cells express very low levels of aquaporins. ation (once anesthetization is accounted for). Recently, an in vivo study has shown fine tuning of astrocyte $\mathrm{Ca}^{2+}$ responses to responses of contiguous neurons in the visual cortex of isoflurane-anesthetized ferrets in response to visual stimulation, ${ }^{82}$ which could then affect vessel diameter by $\mathrm{Ca}^{2+}$ dependent mechanisms, as reported in the recent studies just mentioned. ${ }^{77-82}$ The astrocyte response was more sensitive than that of neurons to increasing levels of isoflurane, and this was used to show that the map of the hemodynamic response depended on the astrocyte $\mathrm{Ca}^{2+}$ response. Understanding which processes control the microcirculation is clearly an area of emerging interest and a topic of importance in several diseases, including cerebrovascular diseases and Alzheimer disease.

Item 6: Water transport and aquaporin 4. The first indication that astrocytes express a high level of water channels or aquaporins was the discovery that the intramembranous particles forming orthogonal arrays predominantly localized at the perivascular membranes of astrocytes around both capillaries and arterioles, ${ }^{83}$ contain a specific isoform of the recently discovered water channels or aquaporins, namely AQP4. ${ }^{84}$ These orthogonal arrays are now a defining characteristic of perivascular astrocytic processes. The intramembranous proteins that form the arrays were originally supposed to be $\mathrm{K}^{+}$channels, in keeping with the $\mathrm{K}^{+}$spatial buffering or siphoning concept, wherein increased $\left[\mathrm{K}^{+}\right]_{\mathrm{o}}$ due to increased neuronal activity would be removed from the CNS by efflux from the astrocyte to the blood. ${ }^{85}$ Recent work has shown that $\mathrm{K}_{\mathrm{ir}} 4.1$ channels, whose RNA and protein $^{13,14}$ are well expressed in astrocytes, are also part of the assemblies. ${ }^{84}$ 
The blood-brain barrier, aquaporins, and astrocytes and their processes are diagrammed in FIG. 5.

Primary astrocyte cultures prepared from Aqp4 knockout mice have a sevenfold reduced water permeability, whereas water transport of some neurons is very slow, ${ }^{12,86}$ consistent with the limited expression of aquaporins in neurons. The function of the astrocytic perivascular AQP4 channels remains unclear. Obviously, their polarized expression in the vascular end-feet of astrocytes suggests that water transport is high, and that astrocytes constitute the major route for water transport into and out of the brain. Endothelial cells, however, have few if any water channels. ${ }^{87}$ Mice with deletion of Aqp 4 developed strikingly smaller infarcts and significant less edema, suggesting that pharmacological inhibition of AQP4 channels could represent a powerful neuroprotective strategy. ${ }^{88}$

Aquaporins are now being shown to have other functions, most importantly facilitating the flux of gases, including $\mathrm{O}_{2}, \mathrm{CO}_{2}$, and $\mathrm{NO} .{ }^{89}$ In fact, the polarized expression of AQP4 in the end-feet facing the vasculature fits well with a channel that facilitates rapid exchange of vital gases. Thus, the neuroprotective action of AQP4 deletion cannot be unequivocally attributed to reduced water fluxes. Unfortunately, these issues are not easily resolved, because no agents to block AQP4 water permeability have yet been identified. ${ }^{90,91}$ Another concern related to the neuroprotective effects of AQP4 is that we must take into the account the extraordinary broad pleiotropic effects of deletion of a protein that is essential to astrocytic function. Parallel examples are the major effects reported for deletion of the gap junction protein connexin $43(\mathrm{Cx} 43){ }^{92}$

Item 7: Astrocyte-neuron lactate shuttle hypothesis. Magistretti and colleagues proposed a hypothesis, termed the astrocyte-neuron lactate shuttle hypothesis, in which glucose enters the CNS via the perivascular endfeet of astrocytic processes and is there converted by aerobic glycolysis to lactate which then serves as the principal food for neurons. ${ }^{93-95}$ As with regulation of blood vessel diameter and thence flow (item 5, above), the underlying morphological characteristics have been recognized since the time of Golgi ${ }^{96}$ and of Ramón y Cajal, ${ }^{97}$ namely, that blood vessels in the CNS are surrounded by astrocytic processes - and we now know that this can be close to $100 \% .^{98}$ This fundamental fact has given rise to many hypotheses, ranging from development of the blood-brain barrier due to signals derived from the astrocytes as the CNS develops to the astrocyte-neuron lactate shuttle hypothesis. It seems that all material that does not diffuse between the astrocytic end-feet will have to pass initially through them, and then be transported out at some location or diffuse through the entire astrocyte and into neighboring ones via the gap junctions. The spaces between the astrocytic

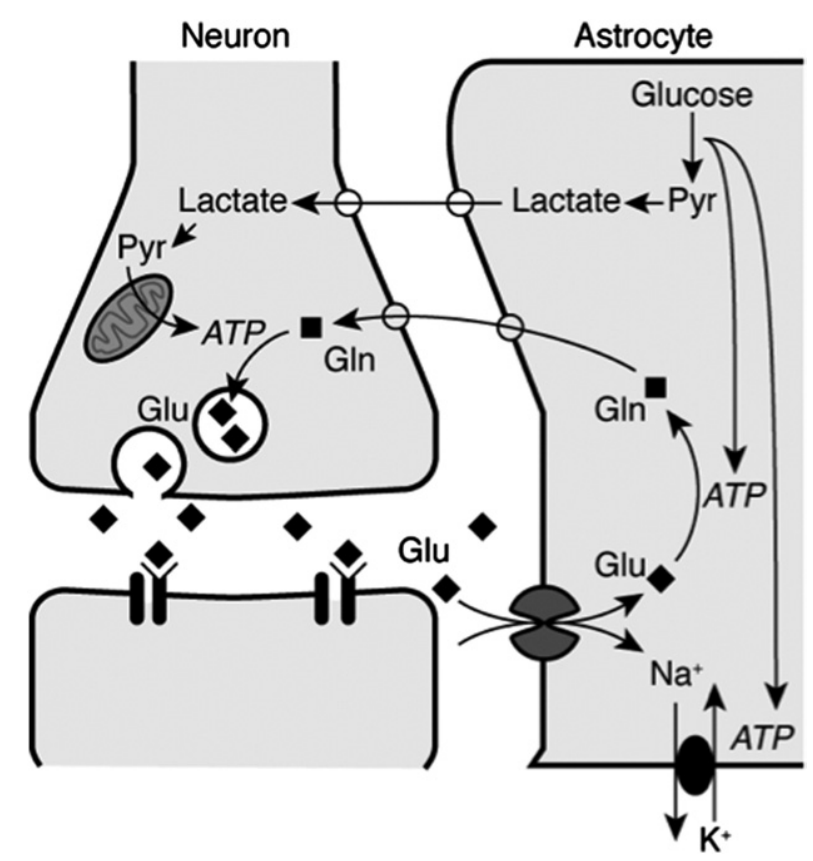

FIG. 7. Lactate shuttle. Schematic diagram of the proposed metabolic coupling between glutamate uptake, lactate production, and compartmentalization of energy metabolism in astrocytes and neurons. Glu = glutamate; Gln = glutamine; Pyr = pyruvate.

processes are of the order of a few hundreds of angstroms wide, so this could still form a major short-circuit path, because the astrocyte membranes would be a major resistance pathway for polar substances unless there are specific carriers on the astrocytic membranes.

A schematic depiction of the lactate shuttle is presented in FIG. 7.

Most of the supporting observations have been made in primary astrocyte cultures, for the usual reasons, but these are convincing only for the cultures. Astrocytes in situ do have the lactate dehydrogenase (LDH) isoform that favors the reductive production of lactate, and neurons have the form that favors oxidation of lactate; however, although astrocytes have the glucose-1 (GLU-1) carrier, there is also a high density of high-affinity GLU-3 transporters on neuronal membranes. ${ }^{99}$ The distribution of the 14 monocarboxylic transporter (MCT) isoforms are yet to be consistently correlated with export of lactate from astrocytes and uptake into neurons. Confirmation in vivo is still lacking, except for one analysis, for which the results can be interpreted in several different ways. ${ }^{100}$

A recent transcriptome report by Lovatt et al. ${ }^{14}$ focused on enzymes and other proteins related to those processes principally involved in producing metabolic energy in astrocytes. The astrocytes were labeled by pGFAP-driven GFP expression, and also stained for GLT-1 after isolation, to also cover a large pool of cells that were not GFAP-GFP positive, and then were sorted 
by means of fluorescence-activated cell sorting. The $\mathrm{pG}$ FAP-GFP ${ }^{-} /$GLT $^{-} 1^{+}$mice had only twofold less of the reliable astrocyte marker AQP4 than the cells that were positive for both markers, but 236 -fold more than Thy $1^{+}$ neurons, as measured by quantitative polymerase chain reaction. The cells were isolated from adult 10- to 12week-old mice using papain. It was found that astrocytes contained transcripts for enzymes involved with glycolytic conversion of glucose to lactate, particularly greater than 13 -fold more LDH-B, which converts pyruvate to lactate, relative to neurons. The LDH-A isozyme, which principally converts lactate to pyruvate, was eightfold enriched in neurons. However, there were also high amounts of all the enzymes involved in the tricarboxylic acid cycle in astrocytes, and mass spectrometric measurements showed that these cycles were active, so the cells do appear to be set up for aerobic glycolysis. Lovatt et al. ${ }^{14}$ also presented electron micrographs that showed high density of mitochondria in $\mathrm{GFP}^{+}$astrocytic processes, around or close to blood vessels.

In terms of the reproducibility of the transcriptome studies, there is at present only one other study for isolated astrocytes. Cahoy et al. ${ }^{13}$ showed equivalent expression of LDH-A in isolated neurons, astrocytes, and even primary cultures; however, expression of the LDH-B isoform was severalfold higher in isolated astrocytes than in neurons, and was also quite high in the primary cultures. Plausible differences are that the oldest mice in the Cahoy et al. ${ }^{13}$ study were only 17 days old, whereas Lovatt et al. ${ }^{14}$ used 10- to 12 -week-old mice, or that Cahoy et al. ${ }^{13}$ used an S-100 $\beta$ promoter, a less selective astrocyte marker, to label the cells.

Thus, although several lines of work point to the existence of the astrocyte-neuron lactate shuttle, definitive in vivo evidence is still lacking. It is also important to remember that neurons express glucose transporters, and that it is likely that multiple alternative pathways exist for something as important as fueling neuronal activity. Manipulation of key proteins involved in the astrocyteneuron lactate shuttle could constitute a potential target for limiting neuronal loss in neurodegenerative diseases.

Item 8: Antioxidant functions. The mammalian CNS is particularly subject to the damaging effects of reactive oxygen species (ROS) because of its high rate of oxidative metabolic activity and its high fatty acid content in the large quantities of myelin and other membranes. The unsaturated carbon-carbon bonds, needed to ensure sufficient fluidity of the fatty acid side chains of the phospholipids, are the ones most susceptible to oxidative damage by ROS. ${ }^{101}$ Reactive oxygen species (the unpaired electron versions of atomic and molecular oxygen) cause the breakdown of a large number of lipid and proteins in an autocatalytic manner. Because the full reduction of molecular oxygen by the respiratory chain will never be complete, these ROS need to be neutral- ized, and antioxidants and enzymes such as catalase and peroxidases are present to neutralize them. Under pathological conditions, however, these protective pathways are overwhelmed, and ROS-induced damage becomes a major source of cellular injury (e.g., in the reperfusion phase of cerebral ischemia).

Astrocytes have a number of antioxidant systems, such as the glutathione disulfide-glutathione (GSSG-GSH) system. ${ }^{102,103}$ Isolated astrocytes also contain messages for the enzymes superoxide dismutase (SOD) and catalase (CAT); however, these two enzymes are not specifically enriched in astrocytes but are found in neurons at reasonably high levels ${ }^{13}$ and, given that they are quite ubiquitous, are likely found in other neural cells as well. Nonetheless, improving antioxidation in astrocytes or limiting their own production of ROS is clearly a powerful strategy for reducing injury in a number of neurological diseases.

Item 9: Müller cells as light guides. An excellent example of a supportive function of astrocytes is the recent suggestion that Müller cells act as light guides. Müller cells are specialized astrocytes of the retina that, similar to other astrocytes, are responsible for glutamate uptake, $\mathrm{K}^{+}$homeostasis, and $\mathrm{pH}$ control. As pointed out in the article originally describing this phenomenon, ${ }^{104}$ the histology of the mammalian eye has always been paradoxical, in that the photoreceptors are located at the back of the retina where light transmission should be degraded by scattering. The orientation and low scattering of the Müller cells makes them able to conduct light to the interior of the retina, much as manufactured optical fibers do, so that it falls on the photoreceptors with less degradation (see rightmost image in FIG. 1C). This property can be best viewed as a support role: allowing light to reach the photoreceptors, where it starts the complex process of being transformed into vision. It is a vital role, given the structure of the retina (why the retina is built this way is another question), and would seem to be best described as facilitative; i.e., it helps the eye's neuronal photoreceptors do their job of performing the initial step of translating light into vision.

Item 10: Perisynaptic processes. It has long been known that the processes of astrocytes wall off groups of neurons and their synapses, similar to glomeruli in the kidney. ${ }^{69}$ Retraction of such ensheathment results in increased interaction levels between neurons, and increases the amount of hormones secreted from the neurons, such as the oxytocin- and vasopressin-secreting neurons in the supraoptic nucleus. ${ }^{105,106} \mathrm{~A}$ much earlier and related suggestion is that this was, by insertion of astrocytic processes into the synaptic cleft, a way of inhibiting synaptic activity. ${ }^{107}$ Pharmacological manipulation of astrocytic coverage of synapses constitutes a potential powerful therapeutic target. However, so far little is 
known with regard to what controls such alterations in the fine structure of astrocytes.

\section{GENERAL SUPPORT THEORY OF MATURE ASTROCYTE FUNCTIONS}

What would a current general support theory of astrocytic function look like? Bushong et al. ${ }^{108}$ emphasized, in their combined immunohistochemical and dye-filling studies of the CA1 region of 1-month-old Sprague-Dawley rats, that the dye-filled astrocytes were morphologically homogeneous and that their highly bushy processes occupied separate territories of $\sim 70,000 \mu \mathrm{m}^{3}$. (See also Ogata and Kasaka. ${ }^{109}$ )

Another study showed that the domain concept also applies to human cortical protoplasmic astrocytes, with a bit more overlap. ${ }^{7}$ This is an important concept for protoplasmic astrocyte function. The domain arrangement of astrocytes can form the lynch pin of a general support theory of astrocyte function in the mature brain - that the vascular and synaptic end-feet function as autonomous units, first responding to specific events at these loci as independent entities driven by local feedback signals. Independent domains for intracellular $\left[\mathrm{Ca}^{2+}\right]$ increases were shown some years back for the Bergmann glia lamellae and filopodia enwrapping the synapses that the Purkinje dendritic spines make with the parallel fibers. ${ }^{110}$ (Reichenbach and Wolburg ${ }^{69}$ discuss micro- to macrodomains based on current detailed morphological understanding.) The simplest mechanism for how astrocytes specialize for their synaptic versus vascular properties would be segregation of functional membrane proteins within the plasma membrane with different transporters, channels and other membrane protein classes on astrocyte end-feet, lamellipodia and filopodia contacting synapses and blood vessels.

This support model of the mature mammalian astrocyte is well grounded in cell and biological principles; processes cannot exist independently of a cell body. The other general biological principle is economy of space. Up to 100,000 synaptic targets, and a lesser number of blood vessels, can be served by one cell soma. Space in the mammalian brains is at a premium, and that has led to myelination, reducing axonal diameters and conserving space for a given action potential velocity. ${ }^{111}$ One could, of course, have more astrocytic cell bodies with fewer processes, and the astrocytic somas are quite small, $\sim 10 \mu \mathrm{m}$ diameter. Presumably, the packing that has evolved is, by definition, optimal. Oberheim et al. ${ }^{1}$ have shown that the domain of protoplasmic astrocytes in the human cortex is 2.6 times larger than in rodents (FIG. 2). At a minimum, this may be the optimal packing relation for astrocytes in the much larger human brain, but the larger volume of the astrocytic domains will also allow human astrocytes to integrate roughly 17 times more information than their rodent equivalents, which could be related to the greater processing power of the human brain.

\section{DOES TARGETING ASTROCYTES TARGET THE CONSEQUENCES RATHER THAN THE PRIMARY CAUSES OF DISEASE?}

Only one disease identified so far is caused by a defect in an astrocytic gene (GFAP) (see the article by Messing, LaPash Daniels, and Hagemann this issue). Another disease with a primary brain malfunction ascribed to astrocytes is hepatic encephalopathy (see the article by Brusilow et al., this issue). This condition is characterized by confusion, altered level of consciousness, and coma in consequence of increases in ammonia and glutamine. Astrocytes are the only cell type in the brain that can detoxify ammonia by conversion of glutamate to glutamine, which in turn interferes with neuronal function.

Astrocytes have been shown to contribute to rather than being the cause of other diseases. One example involves the gene SOD1, encoding superoxide dismutase. Dominant mutations in SOD1 are a frequent cause of inherited amyotrophic lateral sclerosis. Similarly, expression of mutant Sodl in rodents replicates the disease and leads to progressive, selective motor neuron degeneration. ${ }^{12}$ Cleveland and coworkers generated mice carrying a deletable Sod 1 gene. When these mice were crossed with GFAP-Cre mice to delete the mutant gene in astrocytes only, disease progression was sharply reduced; the onset of motor neuron loss and functional deficits were not affected by deletion of the mutant gene in astrocytes. ${ }^{112}$

It is an open question how much the malfunction of astrocytes contributes to neurodegenerative diseases. However, based on the fact that astrocytes are the major supportive cell type in the brain, it seems logical that minor dysfunction of astrocytes over years can contribute to neuronal loss. Moreover, reactive changes of astrocytes may exacerbate pathological changes in other cell types and thereby accelerate disease progression.

\section{POSSIBLE ASTROCYTE DIVERSITY LEADS TO DIFFICULTIES IN ASTROCYTIC PHARMACOLOGICAL TARGETING}

For specific drug targeting, the astrocytes of interest are those of the human brain. Most studies have, of course, been done in mammals with much smaller brains than humans, such as rats and mice. Mice are now being increasingly used, because they can be genetically manipulated. This is especially important for astrocytes because, as argued in more detail elsewhere, ${ }^{6}$ definitive work on astrocytes can only be done in situ and in vivo. 
But, because astrocytes have many of the same receptors and other proteins as neurons and there are, of course, neuron-astrocyte interactions, one is hard-pressed to distinguish direct effects on astrocytes from indirect effects derived from primary effects due to any manipulation on neurons in the complex cellular mosaic of the brain. Astrocyte-specific, promoter-driven genetically altered mice are at present the best approach to definitively altering an astrocyte property in vivo and evaluating functional alterations, especially if an inducible promoter system is used.

\section{CONCLUSIONS}

Current views of the functions and roles of mature astrocytes range from long-known and well-established support roles, such as glutamate uptake at synapses, to recent proposals, such as the ability of astrocytes to modulate and control synaptic activity though the release of neurotransmitters such as glutamate and ATP. ${ }^{17,113,114}$ The evidence supporting the latter possibility is still in preliminary phases, and some of the observations used to support the concept are in dispute.

How do we best target astrocytes pharmacologically? The concept of the astrocyte as a supportive component of the CNS is well-established and comprehensive, although we lack a detailed mechanistic understanding of, for example, the pathways by which astrocytes buffer potassium or control water homeostasis. Thus, a clear understanding of the molecular mechanisms underlying the well-established supportive function of astrocytes represents the fastest approach for efficient pharmacological targeting of astrocytes.

Acknowledgments: We thank Takahiro Takano for graphics and Jon Goldman for comments on the manuscript. This work was supported in part by the U.S. National Institutes of Health grant no. NS50350, and funding from the Leila Y. and G. Harold Mathers Charitable Foundation, both MN. We thank Nancy Ann Oberheim for the images used in Figure 2.

\section{REFERENCES}

1. Oberheim NA, Wang X, Goldman S, Nedergaard M. Astrocytic complexity distinguishes the human brain. Trends Neurosci 2006; 29:547-553.

2. Kettenmann H, Ransom B. The concept of neuroglia: a historical perspective. In: Kettenmann H, Ransom BR, editors. Neuroglia. 2nd ed. New York: Oxford University Press, 2005:1-16.

3. Nedergaard M, Ransom B, Goldman SA. New roles for astrocytes: redefining the functional architecture of the brain. Trends Neurosci 2003;26:523-530.

4. Somjen GG. Nervenkitt: notes on the history of the concept of neuroglia. Glia 1988;1:2-9.

5. Kimelberg HK. Supportive or information-processing functions of the mature protoplasmic astrocyte in the mammalian CNS? A critical appraisal. Neuron Glia Biol 2007;3:181-189.

6. Kimelberg HK. Functions of mature mammalian astrocytes: a current view. Neuroscientist 2010;16:79-106.

7. Oberheim NA, Takano T, Han X, et al. Uniquely hominid features of adult human astrocytes. J Neurosci 2009;29:3276-3287.
8. Colombo JA, Reisin HD. Interlaminar astroglia of the cerebral cortex: a marker of the primate brain. Brain Res 2004;1006:126131.

9. Luo L, Callaway EM, Svoboda K. Genetic dissection of neural circuits. Neuron 2008;57:634-660.

10. Fiacco T, Casper K, Sweger E, et al. Molecular approaches for studying astrocytes. In: Parpura V, Haydon PG, editors. Astrocytes in (patho)physiology of the nervous system. New York: Springer, 2009:383-405.

11. Kimelberg HK. The problem of astrocyte identity. Neurochem Int 2004:45:191-202.

12. Kimelberg HK. Water homeostasis in the brain: basic concepts. Neuroscience 2004;129:851-860.

13. Cahoy JD, Emery B, Kaushal A, et al. A transcriptome database for astrocytes, neurons, and oligodendrocytes: a new resource for understanding brain development and function. J Neurosci 2008; 28:264-278.

14. Lovatt D, Sonnewald U, Waagepetersen HS, et al. The transcriptome and metabolic gene signature of protoplasmic astrocytes in the adult murine cortex. J Neurosci 2007;27:12255-12266.

15. Olsen ML, Sontheimer H. Voltage-activated ion channels in glial cells. In: Kettenmann H, Ransom BR, editors. Neuroglia. 2nd ed. Oxford, New York: Oxford University Press, 2005:112-130.

16. Houades V, Koulakoff A, Ezan P, Seif I, Giaume C. Gap junction-mediated astrocytic networks in the mouse barrel cortex. J Neurosci 2008;28:5207-5217.

17. Henneberger C, Papouin T, Oliet SH, Rusakov DA. Long-term potentiation depends on release of D-serine from astrocytes. Nature 2010;463:232-236.

18. Zhou M, Xu G, Xie M, et al. TWIK-1 and TREK-1 are potassium channels contributing significantly to astrocyte passive conductance in rat hippocampal slices. J Neurosci 2009;29:8551-8564.

19. Sontheimer H. Whole-cell patch-clamp recordings. In: Boulton A, Baker GB, Walz W, editors. Patch-clamp applications and protocols. Totowa, NJ: Humana Press, 1995;37-74.

20. Xu G, Wang W, Kimelberg HK, Zhou M. Electrical coupling of astrocytes in rat hippocampal slices under physiological and simulated ischemic conditions. Glia 2010;58:481-493.

21. Giaume C, Koulakoff A, Roux L, Holcman D, Rouach N. Astroglial networks: a step further in neuroglial and gliovascular interactions. Nat Rev Neurosci 2010;11:87-99.

22. Kuffler SW, Nicholls JG, Orkand RK. Physiological properties of glial cells in the central nervous system of amphibia. J Neurophysiol 1966;29:768-787.

23. Picker S, Pieper CF, Goldring S. Glial membrane potentials and their relationship to $\left[\mathrm{K}^{+}\right]_{\mathrm{o}}$ in man and guinea pig. $\mathrm{J}$ Neurosurg 1981;55:347-363.

24. Walz W, Hertz L. Intense furosemide-sensitive potassium accumulation in astrocytes in the presence of pathologically high extracellular potassium levels. J Cereb Blood Flow Metab 1984; 4:301-304.

25. Orkand RK, Nicholls JG, Kuffler SW. Effect of nerve impulses on the membrane potential of glial cells in the central nervous system of amphibia. J Neurophysiol 1966;29:788-806.

26. Gardner-Medwin AR. Study of the mechanisms by which potassium moves through brain tissue in the rat. J Physiol 1983;335: 353-374.

27. Kofuji P, Newman EA. Potassium buffering in the central nervous system. Neuroscience 2004;129:1045-1056.

28. Metea MR, Kofuji P, Newman EA. Neurovascular coupling is not mediated by potassium siphoning from glial cells. J Neurosci 2007;27:2468-2471.

29. Wallraff A, Köhling R, Heinemann U, Theis M, Willecke K, Steinhäuser C. The impact of astrocytic gap junctional coupling on potassium buffering in the hippocampus. J Neurosci 2006;26: $5438-5447$.

30. D'Ambrosio R, Gordon DS, Winn HR. Differential role of KIR channel and $\mathrm{Na}^{+} / \mathrm{K}^{+}$-pump in the regulation of extracellular $\mathrm{K}^{+}$ in rat hippocampus. J Neurophysiol 2002;87:87-102.

31. Walz W, Wuttke WA. Independent mechanisms of potassium clearance by astrocytes in gliotic tissue. J Neurosci Res 1999;56: 595-603. 
32. Walz W. Role of astrocytes in the clearance of excess extracellular potassium. Neurochem Int 2000;36:291-300.

33. Bergles DE, Jahr CE. Synaptic activation of glutamate transporters in hippocampal astrocytes. Neuron 1997;19:1297-1308.

34. Magistretti PJ, Pellerin L. Astrocytes couple synaptic activity to glucose utilization in the brain. News Physiol Sci 1999;14:177182.

35. Lalo U, Pankratov Y, Kirchhoff F, North RA, Verkhratsky A. NMDA receptors mediate neuron-to-glia signaling in mouse cortical astrocytes. J Neurosci 2006;26:2673-2683.

36. Fischer W, Appelt K, Grohmann M, Franke H, Nörenberg W, Illes $\mathrm{P}$ Increase of intracellular $\mathrm{Ca}^{2+}$ by $\mathrm{P} 2 \mathrm{X}$ and $\mathrm{P} 2 \mathrm{Y}$ receptorsubtypes in cultured cortical astroglia of the rat. Neuroscience 2009;160:767-783.

37. Walz W. Mechanism of rapid $\mathrm{K}^{+}$-induced swelling of mouse astrocytes. Neurosci Lett 1992;135:243-246.

38. Hodgkin AL, Horowicz P. Influence of potassium and chloride ions on the membrane potential of single muscle fibres. J Physiol 1959;148:127-160.

39. Amzica F, Massimini M. Glial and neuronal interactions during slow wave and paroxysmal activities in the neocortex. Cereb Cortex 2002;12:1101-1113.

40. Tschirgi RD. The blood-brain barrier. In: Windle WF, editor. Biology of neuroglia. Springfield, IL: Charles C. Thomas, 1958: $130-138$.

41. Kimelberg HK, Stieg PE, Mazurkiewicz JE. Immunocytochemical and biochemical analysis of carbonic anhydrase in primary astrocyte cultures from rat brain. J Neurochem 1982;39:734-742.

42. Kimelberg HK, Biddlecome S, Bourke RS. SITS-inhibitable $\mathrm{Cl}^{-}$ transport and $\mathrm{Na}^{+}$-dependent $\mathrm{H}^{+}$production in primary astroglial cultures. Brain Res 1979;173:111-124.

43. Kimelberg HK. Active accumulation and exchange transport of chloride in astroglial cells in culture. Biochim Biophys Acta 1981;646:179-184.

44. Rose CR, Ransom BR. pH regulation in mammalian glia. In: Kaila K, Ransom BR, editors. $\mathrm{pH}$ and brain function. New York: Wiley-Liss, 1998:253-276.

45. Schmitt BM, Berger UV, Douglas RM, et al. $\mathrm{Na} / \mathrm{HCO}_{3}$ cotransporters in rat brain: expression in glia, neurons, and choroid plexus. J Neurosci 2000;20:6839-6848.

46. Majumdar D, Maunsbach AB, Shacka JJ, et al. Localization of electrogenic $\mathrm{Na} /$ bicarbonate cotransporter $\mathrm{NBCe} 1$ variants in rat brain. Neuroscience 2008;155:818-832.

47. Parker MD, Bouyer P, Daly CM, Boron WF. Cloning and characterization of novel human SLC4A8 gene products encoding $\mathrm{Na}^{+}$-driven $\mathrm{Cl}^{-} / \mathrm{HCO}_{3}{ }^{-}$exchanger variants NDCBE-A, -C, and -D. Physiol Genomics 2008;34:265-276.

48. Pellerin L, Magistretti PJ. Neuroenergetics: calling upon astrocytes to satisfy hungry neurons. Neuroscientist 2004;10:53-62.

49. Robergs RA, Ghiasvand F, Parker D. Biochemistry of exerciseinduced metabolic acidosis. Am J Physiol Regul Integr Comp Physiol 2004;287:R502-R516.

50. Krnjević K, Schwartz S. Some properties of unresponsive cells in the cerebral cortex. Exp Brain Res 1967;3:306-319.

51. Constanti A, Galvan M. Amino acid evoked depolarization of electrically inexcitable (neuroglial?) cells in the guinea pig olfactory cortex slice. Brain Res 1978;153:183-187.

52. Bowman CL, Kimelberg HK. Excitatory amino acids directly depolarize rat brain astrocytes in primary culture. Nature 1984; 311:656-659.

53. Kettenmann H, Backus KH, Schachner M. Aspartate, glutamate and $\gamma$-aminobutyric acid depolarize cultured astrocytes. Neurosci Lett 1984;52:25-29.

54. Kimelberg HK. Glial cell receptors. New York, NY: Raven Press, 1988.

55. Zhou M, Kimelberg HK. Freshly isolated hippocampal CA1 astrocytes comprise two populations differing in glutamate transporter and AMPA receptor expression. J Neurosci 2001;21:79017908.

56. Iino M, Goto K, Kakegawa W, et al. Glia-synapse interaction through $\mathrm{Ca}^{2+}$-permeable AMPA receptors in Bergmann glia. Science 2001;292:926-929.
57. Hertz L, Peng L, Dienel GA. Energy metabolism in astrocytes: high rate of oxidative metabolism and spatiotemporal dependence on glycolysis/glycogenolysis. J Cereb Blood Flow Metab 2007; 27:219-249.

58. Berl S, Lajtha A, Waelsch H. Amino acid and protein metabolism. VI: Cerebral compartments of glutamic acid metabolism. J Neurochem 1961;7:186-197.

59. Rothstein JD, Dykes-Hoberg M, Pardo CA, et al. Knockout of glutamate transporters reveals a major role for astroglial transport in excitotoxicity and clearance of glutamate. Neuron 1996;16: $675-686$.

60. Minelli A, Brecha NC, Karschin C, DeBiasi S, Conti F. GAT-1, a high-affinity GABA plasma membrane transporter, is localized to neurons and astroglia in the cerebral cortex. J Neurosci 1995 15:7734-7746.

61. Minelli A, DeBiasi S, Brecha NC, Zuccarello LV, Conti F. GAT-3, a high-affinity GABA plasma membrane transporter, is localized to astrocytic processes, and it is not confined to the vicinity of GABAergic synapses in the cerebral cortex. J Neurosci 1996;16:6255-6264.

62. Ribak CE, Tong WM, Brecha NC. GABA plasma membrane transporters, GAT-1 and GAT-3, display different distributions in the rat hippocampus. J Comp Neurol 1996;367:595-606.

63. Håberg A, Qu H, Saether O, Unsgård G, Haraldseth O, Sonnewald U. Differences in neurotransmitter synthesis and intermediary metabolism between glutamatergic and GABAergic neurons during 4 hours of middle cerebral artery occlusion in the rat: the role of astrocytes in neuronal survival. J Cereb Blood Flow Metab 2001;21:1451-1463.

64. Yang Y, Rothstein JD. Specialized neurotransmitter transporters in astrocytes. In: Parpura V, Haydon PG, editors. Astrocytes in (patho)physiology of the nervous system. New York: Springer, 2009;69-106.

65. Warskulat U, Heller-Stilb B, Oermann E, et al. Phenotype of the taurine transporter knockout mouse. Methods Enzymol 2007;428: 439-458.

66. Rothstein JD, Patel S, Regan MR, et al. $\beta$-Lactam antibiotics offer neuroprotection by increasing glutamate transporter expression. Nature 2005;433:73-77.

67. Thöne-Reineke C, Neumann C, Namsolleck P, et al. The $\beta$-lactam antibiotic, ceftriaxone, dramatically improves survival, increases glutamate uptake and induces neurotrophins in stroke. J Hypertens 2008;26:2426-2435.

68. Lipski J, Wan CK, Bai JZ, Pi R, Li D, Donnelly D. Neuroprotective potential of ceftriaxone in in vitro models of stroke. Neuroscience 2007;146:617-629.

69. Reichenbach A, Wolburg H. Structural association of astrocytes with neurons and vasculature: defining territorial boundaries. In: Parpura V, Haydon PG, editors. Astrocytes in (patho)physiology of the nervous system. New York: Springer, 2009:251-286.

70. Zonta M, Angulo MC, Gobbo S, et al. Neuron-to-astrocyte signaling is central to the dynamic control of brain microcirculation. Nat Neurosci 2003;6:43-50.

71. Anderson CM, Nedergaard M. Astrocyte-mediated control of cerebral microcirculation. Trends Neurosci 2003;26:340-344.

72. Traystman RJ. Regulation of cerebral blood flow by carbon dioxide. In: Welch KMA, Caplan LR, Reis DJ, Siesjö BK, Weir B, editors. Primer on cerebrovascular diseases. San Diego/London: Academic Press, 1997:55-58.

73. Edvinsson L, MacKenzie ET, McCulloch J. Vascular smooth muscle reactivity in vitro and in situ. In: Cerebral blood flow and metabolism. New York: Raven Press, 1993:113-141.

74. Abbott NJ. Astrocyte-endothelial interactions and blood-brain barrier permeability. J Anat 2002;200:629-638.

75. Pardridge WM. Drug delivery to the brain. J Cereb Blood Flow Metab 1997;17:713-731

76. Paulson OB, Newman EA. Does the release of potassium from astrocyte endfeet regulate cerebral blood flow? Science 1987;237: 896-898.

77. Gordon GR, Choi HB, Rungta RL, Ellis-Davies GC, MacVicar BA. Brain metabolism dictates the polarity of astrocyte control over arterioles. Nature 2008;456:745-749. 
78. Koehler RC, Roman RJ, Harder DR. Astrocytes and the regulation of cerebral blood flow. Trends Neurosci 2009;32:160-169.

79. Girouard H, Iadecola C. Neurovascular coupling in the normal brain and in hypertension, stroke, and Alzheimer disease. J Appl Physiol 2006;100:328-335.

80. Takano T, Tian GF, Peng W, et al. Astrocyte-mediated control of cerebral blood flow. Nat Neurosci 2006;9:260-267.

81. Iadecola C, Nedergaard M. Glial regulation of the cerebral microvasculature. Nat Neurosci 2007;10:1369-1376.

82. Schummers J, Yu H, Sur M. Tuned responses of astrocytes and their influence on hemodynamic signals in the visual cortex. Science 2008;320:1638-1643.

83. Landis DMD, Reese TS. Membrane structure in mammalian astrocytes: a review of freeze fracture studies on adult, developing, reactive and cultured astrocytes. J Exp Biol 1981;95:35-48.

84. Amiry-Moghaddam M, Ottersen OP. The molecular basis of water transport in the brain. Nat Rev Neurosci 2003;4:991-1001.

85. Newman EA. High potassium conductance in astrocyte endfeet. Science 1986;233:453-454.

86. Aitken PG, Borgdorff AJ, Juta AJA, Kiehart DP, Somjen GG, Wadman WJ. Volume changes induced by osmotic stress in freshly isolated rat hippocampal neurons. Pflugers Arch 1998; 436:991-998.

87. Badaut J, Brunet JF, Regli L. Aquaporins in the brain: from aqueduct to "multi-duct". Metab Brain Dis 2007;22:251-263.

88. Manley GT, Fujimura M, Ma T, et al. Aquaporin-4 deletion in mice reduces brain edema after acute water intoxication and ischemic stroke. Nat Med 2000;6:159-63.

89. Verkman AS. Knock-out models reveal new aquaporin functions. Handb Exp Pharmacol 2009;(190):359-381.

90. Verkman AS. Water permeability measurement in living cells and complex tissues. J Membr Biol 2000;173:73-87.

91. Amiry-Moghaddam M, Otsuka T, Hurn PD, et al. An $\alpha$-syntrophin-dependent pool of AQP4 in astroglial end-feet confers bidirectional water flow between blood and brain. Proc Natl Acad Sci U S A 2003;100:2106-2111.

92. Iacobas DA, Scemes E, Spray DC. Gene expression alterations in connexin null mice extend beyond the gap junction. Neurochem Int 2004;45:243-250.

93. Magistretti PJ, Sorg O, Naichen Y, Pellerin L, de Rham S, Martin JL. Regulation of astrocyte energy metabolism by neurotransmitters. Renal Physiol Biochem 1994;17:168-171.

94. Pellerin L, Magistretti PJ. Food for thought: challenging the dogmas. J Cereb Blood Flow Metab 2003;23:1282-1286.

95. Voutsinos-Porche B, Bonvento G, Tanaka K, et al. Glial glutamate transporters mediate a functional metabolic crosstalk between neurons and astrocytes in the mouse developing cortex. Neuron 2003;37:275-286.

96. Golgi C. Sulla fina anatomia degli organi centrali del sistema nervosa [In Italian]. Riv Sper Fremiat Med Leg Alienazione Ment 1885;11:72-123.

97. Ramón y Cajal S. Contribución al conocimiento de la neuroglia del cerebro humano [Contribution to the understanding of neuroglia in the human cerebrum] [In Spanish]. Trab Lab Invest Biol Univ Madrid 1913;11:255-315.

98. Virgintino D, Monaghan P, Robertson D, et al. An immunohistochemical and morphometric study on astrocytes and microvasculature in the human cerebral cortex. Histochem J 1997;29:655660.

99. Leino RL, Gerhart DZ, van Bueren AM, McCall AL, Drewes LR. Ultrastructural localization of GLUT 1 and GLUT 3 glucose transporters in rat brain. J Neurosci Res 1997;49:617-626.

100. Sibson NR, Shen J, Mason GF, Rothman DL, Behar KL, Shulman RG. Functional energy metabolism: in vivo ${ }^{13} \mathrm{C}-\mathrm{NMR}$ spectroscopy evidence for coupling of cerebral glucose consumption and glutamatergic neuronal activity. Dev Neurosci 1998;20:321-330.

101. Halliwell B, Gutteridge JMC. Free radicals in biology and medicine. 3rd ed. Oxford, New York: Oxford University Press, 1999.

102. Aschner M. Neuron-astrocyte interactions: implications for cellular energetics and antioxidant levels. Neurotoxicology 2000;21: 1101-1107.

103. Anderson MF, Blomstrand F, Blomstrand C, Eriksson PS, Nilsson
M. Astrocytes and stroke: networking for survival? Neurochem Res 2003;28:293-305.

104. Franze K, Grosche J, Skatchkov SN, et al. Müller cells are living optical fibers in the vertebrate retina. Proc Natl Acad Sci U S A 2007; 104:8287-8292.

105. Hatton GI. Astroglial modulation of neurotransmitter peptide release from the neurohypophysis: present status. J Chem Neuroanat 1999;16:203-221.

106. Brès V, Hurbin A, Duvoid A, et al. Pharmacological characterization of volume-sensitive, taurine permeable anion channels in rat supraoptic glial cells. Br J Pharmacol 2000;130:1976-1982.

107. Dierig S. Extending the neuron doctrine: Carl Ludwig Schleich (1859-1922) and his reflections on neuroglia at the inception of the neural-network concept in 1894. Trends Neurosci 1994;17: 449-452.

108. Bushong EA, Martone ME, Ellisman MH. Maturation of astrocyte morphology and the establishment of astrocyte domains during postnatal hippocampal development. Int J Dev Neurosci 2004;22:73-86.

109. Ogata K, Kosaka T. Structural and quantitative analysis of astrocytes in the mouse hippocampus. Neuroscience 2002;113:221233.

110. Grosche J, Matyash V, Möller T, Verkhratsky A, Reichenbach A, Kettenmann H. Microdomains for neuron-glia interaction: parallel fiber signaling to Bergmann glial cells. Nat Neurosci 1999; 2:139-143.

111. Hille B. Ionic channels of excitable membranes. 2nd ed. Sunderland, MA: Sinauer Associates, 1992.

112. Yamanaka K, Boillee S, Roberts EA, et al. Mutant SOD1 in cell types other than motor neurons and oligodendrocytes accelerates onset of disease in ALS mice. Proc Natl Acad Sci U S A 200105:7594-7599.

113. Perea G, Navarrete M, Araque A. Tripartite synapses: astrocytes process and control synaptic information. Trends Neurosci 2009; 32:421-431.

114. Haydon PG, Carmignoto G. Astrocyte control of synaptic transmission and neurovascular coupling. Physiol Rev 2006;86:10091031.

115. Lothman EW, Somjen GG. Extracellular potassium activity intracellular and extracellular potential responses in the spinal cord. J Physiol 1975;252:115-136.

116. Dietzel I, Heinemann U, Hofmeier G, Lux HD. Transient changes in the size of the extracellular space in the sensorimotor cortex of cats in relation to stimulus-induced changes in potassium concentrations. Exp Brain Res 1980;40:432-439.

117. Kimelberg HK. Anisotonic media and glutamate-induced ion transport and volume responses in primary astrocyte cultures. J Physiol (Paris) 1987;82:294-303.

118. McGrail KM, Sweadner KJ. Immunofluorescent localization of two different $\mathrm{Na}, \mathrm{K}$-ATPases in the rat retina and in identified dissociated retinal cells. J Neurosci 1986;6:1272-1283.

119. Leis JA, Bekar LK, Walz W. Potassium homeostasis in the ischemic brain. Glia 2005;50:407-416.

120. Somjen GG. Ions in the brain: normal function, seizures, and stroke. Oxford, New York: Oxford University Press, 2004.

121. Deitmer JW, Rose CR. Ion changes and signalling in perisynaptic glia. Brain Res Rev 2010;63:113-29.

122. Obara M, Szeliga M, Albrecht J. Regulation of $\mathrm{pH}$ in the mammalian central nervous system under normal and pathological conditions: facts and hypotheses. Neurochem Int 2008;52:905919.

123. Chesler M. Regulation and modulation of $\mathrm{pH}$ in the brain. Physiol Rev 2003;83:1183-1221.

124. van Calker D, Muiller M, Hamprecht B. In: Meisami E, Brazier MAB, editors. Neural growth and differentiation. Int Brain Res Org Monogr Ser 5. New York: Raven Press, 1979:11-25.

125. McCarthy KD, de Vellis J. $\alpha$-Adrenergic receptor modulation of $\beta$-adrenergic, adenosine and prostaglandin E-1 increased adenosine $3^{\prime}: 5^{\prime}$-cyclic monophosphate levels in primary cultures of glia. J Cyclic Nucleotide Res 1978;4:15-26.

126. Halassa MM, Fellin T, Haydon PG. The tripartite synapse: roles for gliotransmission in health and disease. Trends Mol Med 2007; $13: 54-63$. 
127. Volterra A, Meldolesi J. Astrocytes, from brain glue to communication elements: the revolution continues. Nat Rev Neurosci 2005;6:626-640.

128. Newman EA. Glial modulation of synaptic transmission in the retina. Glia 2004;47:268-274.

129. Martinez-Hernandez A, Bell K, Norenberg MD. Glutamine synthetase: glial localization in brain. Science 1977;195:1356-1358.

130. Schousboe A, Hertz L, Svenneby G. Uptake and metabolism of GABA in astrocytes cultured from dissociated mouse brain hemispheres. Neurochem Res 1977;2:217-229.

131. Levi G, Wilkin GP, Ciotti MT, Johnstone S. Enrichment of differentiated, stellate astrocytes in cerebellar interneuron cultures as studied by GFAP immunofluorescence and autoradiographic uptake patterns with $\left[{ }^{3} \mathrm{H}\right]$ aspartate and $\left[{ }^{3} \mathrm{H}\right] \mathrm{GABA}$. Brain Res 1983; 312:227-241.

132. Sattler R, Rothstein JD. Regulation and dysregulation of glutamate transporters. Handb Exp Pharmacol 2006;175:277-303.

133. Anderson CM, Swanson RA. Astrocyte glutamate transport: review of properties, regulation, and physiological functions. Glia 2000;32:1-14.

134. Nielsen S, Nagelhus EA, Amiry-Moghaddam M, Bourque C, Agre P, Ottersen OP. Specialized membrane domains for water transport in glial cells: high-resolution immunogold cytochemistry of aquaporin-4 in rat brain. J Neurosci 1997;17:171-180.

135. King LS, Kozono D, Agre P. From structure to disease: the evolving tale of aquaporin biology. Nat Rev Mol Cell Biol 2004;5:687-698.

136. Pellerin L, Magistretti PJ. Excitatory amino acids stimulate aerobic glycolysis in astrocytes via an activation of the $\mathrm{Na}^{+} / \mathrm{K}^{+}$ ATPase. Dev Neurosci 1996;18:336-342.

137. Magistretti PJ. Role of glutamate in neuron-glia metabolic coupling. Am J Clin Nutr 2009;90:875S-880S.

138. Dienel GA, Cruz NF. Nutrition during brain activation: does cell-to-cell lactate shuttling contribute significantly to sweet and sour food for thought? Neurochem Int 2004;45:321-351.

139. Jou MJ. Pathophysiological and pharmacological implications of mitochondria-targeted reactive oxygen species generation in astrocytes. Adv Drug Deliv Rev 2008;60:1512-1526.

140. Hatton GI, Bicknell RJ, Hoyland J, Bunting R, Mason WT. Arginine vasopressin mobilises intracellular calcium via $\mathrm{V}_{1}$-receptor activation in astrocytes (pituicytes) cultured from adult rat neural lobes. Brain Res 1992;588:75-83.

141. Deleuze C, Duvoid A, Hussy N. Properties and glial origin of osmotic-dependent release of taurine from the rat supraoptic nucleus. J Physiol 1998;507:463-471.

142. Theodosis DT, Poulain DA, Oliet SHR. Activity-dependent structural and functional plasticity of astrocyte-neuron interactions. Physiol Rev 2008;88:983-1008.

143. Verkhratsky A, Orkand RK, Kettenmann H. Glial calcium: homeostasis and signaling function. Physiol Rev 1998;78:99-141. 